\title{
KETERLAKSANAAN GERAKAN LITERASI BAHASA BERBASIS KELAS \\ PADA JENJANG SEKOLAH DASAR DI PULAU LOMBOK: PELUANG PEMANFAATAN TEKNOLOGI DIGITAL SEBAGAI UPAYA OPTIMALISASI
}

\section{IMPLEMENTATION OF CLASS-BASED LANGUAGE LITERACY MOVEMENTS AT THE ELEMENTARY SCHOOL LEVEL IN LOMBOK: AN OPTIMUM EFFORT AND OPPORTUNITY FOR UTILIZING DIGITAL TECHNOLOGY}

\author{
Syaiful Musaddat ${ }^{1}$, A.A.I.N. Marhaeni ${ }^{2}$ \\ ${ }^{1}$ Universitas Mataram \\ Jalan Majapahit Nomor 62 Mataram, 83125 \\ ${ }^{2}$ Universitas Pendidikan Ganesha \\ Jalan Udayana 11 Singaraja, 81116
}

\begin{abstract}
${ }^{1}$ Ponsel: 081339535648; Pos-el: syaiful_musaddat@unram.ac.id
2Ponsel: 0817567427; Pos-el: ngurahmarhaeni2603@gmail.com
\end{abstract}

\begin{abstract}
Abstrak
Pembelajaran abad 21 menghendaki penguasaan literasi tidak hanya pada literasi bahasa dan numerasi, tetapi juga literasi sains, digital, finansial, serta budaya dan kewarganegaaran. Gerakan Literasi Sekolah belum maksimal mendukung target tersebut. Padahal, sekolah-sekolah telah melaksanakan gerakan literasi sekolah sejak tahun 2016 berdasarkan Permendikbud Nomor 23 tahun 2015 tentang penumbuhan minat baca melalui kegiatan 15 menit membaca. Di Sekolah Dasar Pulau Lombok, efektivitas pelaksanaan literasi bahasa berbasis kelas masih jauh dari harapan. Tulisan ini terkait dengan 2 permasalahan, yakni (1) pelaksanaan literasi bahasa berbasis kelas di Sekolah Dasar Pulau Lombok; dan (2) Pemanfaatan teknologi digital sebagai alternatif solusi dalam mengoptimalkan pelaksanaan literasi bahasa berbasis kelas di Sekolah Dasar Pulau Lombok. Kajian dilakukan dengan melakukan observasi dan FGD terhadap beberapa guru dan beberapa sekolah dasar di Pulau Lombok. Data dianalisis dengan metode deskriptif kualitatif. Hasil kajian menunjukkan: (1) Keterlaksanaan literasi bahasa berbasis kelas di SD Pulau Lombok belum efektif. Indikatornnya antara lain: (a) penataan ruang kelas belum mendukung, (b) jadwal kegiatan literasi kelas tidak ada, (c) kegiatan litersi kelas belum tercermin pada RPP dan Pelaksanaan Pembelajaran, dan (d) tidak melibatkan keluarga dan masyarakat dalam pelaksanaan program literasi; dan (2) Literasi bahasa berbasis kelas di SD Pulau Lombok perlu sentuhan magis berupa: (a) memberi sentuhan teknologi digital dalam menata struktur kelas, (b) mengembangkan pemahaman komprehensif pelaku literasi, (c) melatih guru merancang dan melaksanakan literasi
\end{abstract}


terutama dengan memanfaatkan teknologi digital, dan (d) memanfaatkan teknologi digital dalam membangun hubungan dengan keluarga dan masyarakat dalam pelaksanaan literasi.

Kata kunci: gerakan literasi; literasi bahasa; berbasis kelas; teknologi digital; optimalisasi

\begin{abstract}
Learning in the $21^{\text {st }}$ century does not only requires mastery of language and numeral literacy, but also scientific, digital, financial, and cultural and civic literacy. The School Literacy Movement has not sustained the target maximally. In fact, many schools have executed the School Literacy Movement since 2016 based on The Regulation of Minister of Education and Culture Number 23 of 2015 concerning developing reading interest in the form of 15-minute reading activity. Implementation of the classroom-based language literacy in the Elementary Schools in Lombok is still far from expectations. This paper deals with 2 problems, namely (1) the implementation of class-based language literacy in The Elementary Schools in Lombok; and (2) Utilization of digital technology as an alternative solution for optimizing the implementation of classroom-based language literacy in Lombok. The study is conducted by observing teachers and holding FGDs in several elementary schools in Lombok. The data is analyzed using qualitative descriptive methods. The results of the study show that (1) Implementation of class-based language literacy in several elementary school in Lombok Island is still ineffective, the indicators include: (a) not supported by classrooms arrangement, (b) the absence of class literacy activity schedules, (c) class literacy activities have not been included in RPP and Learning Implementation, and (d) the Family and the community are not involved in the implementation of literacy programs; and (2) Class-based language literacy in the Elementary School in Lombok requires magical touch in the form of: (a) providing digital technology touch to arrange class structure, (b) improving comprehensive understanding of the literacy practitioners, (c) training teachers to design and implement literacy especially by utilizing digital technology, and (d) utilizing digital technology in building relationships with family and the communities for the implementation of literacy.
\end{abstract}

Keywords: literacy movement; language literacy; class-based; digital technology 


\section{Pendahuluan}

Tuntutan pembelajaran abad 21 telah memaksa penguasaan literasi yang sangat kompleks. Pengusaan literasi tidak lagi hanya terbatas pada kemampuan membaca, menulis, dan berhitung. Literasi kini terpapar pada berbagai bentuk dan dimensi yang lebih luas, yaitu literasi bahasa, numerasi, sains, digital, finansial, serta budaya dan kewarganegaaran. Oleh karena itu, literasi kemudian bermakna kemampuan individu untuk membaca, menulis, berbicara, berhitung, dan memecahkan masalah pada tingkat keahlian yang diperlukan dalam pekerjaan, keluarga, dan masyarakat. Dalam konteks pemanfaatannya, literasi bahasa menjadi jenis literasi yang sangat penting. Hal ini karena literasi bahasa merupakan penghela atau yang menjembatani penguasaan literasi-literasi yang lainnya. Melalui penguasaan literasi bahasa, literasi yang lainnya akan semakin cepat diperoleh.

Program literasi di Indonesia dikenal dengan nama Gerakan Literasi Sekolah (GLS). GLS mulai digagas sejak tahun 2015 melalui Permendikbud Nomor 23 Tahun 2015 tentang Penumbuhan Minat Baca melalui Kegiatan 15 Menit Membaca. Jika dicermati bentuk-bentuk kegiatannya, GLS sesungguhnya sangat terkait dengan literasi bahasa. Pada konteks ini, dapat dimaknai bahwa Indonesia telah dan sedang menggalakkan literasi bahasa melalui program GLS. GLS melibatkan semua pemangku kepentingan di bidang pendidikan, mulai dari tingkat pusat, provinsi, kabupaten/kota, hingga satuan pendidikan. Selain itu, GLS juga melibatkan unsur eksternal dan unsur publik, seperti orang tua peserta didik, alumni, masyarakat, dunia usaha dan industri (Depdikbud, 2018).

GLS dilaksanakan melalui tiga tahapan utama, yakni pembiasaan, pengembangan, dan pembelajaran. Tahapan ini dapat dilaksanakan di kelas (berbasis kelas), di sekolah (berbasis sekolah), dan masyarakat (berbasis masyarakat). Dalam hal ini, semua bentuk dan dimenasi literasi sebagamana disebutkan di atas juga dapat dilaksanakan pada ketiga basis ini. Demikian pula literasi bahasa, juga dapat dilaksanakan berbasis kelas, sekolah, ataupun masyarakat.

Literasi bahasa berbasis kelas bermakna kegiatan literasi bahasa yang dilaksanakan terutama di kelas. Mengacu pada panduan pelaksanaan 
GLS, dapat dijelaskan bahwa terdapat sejumlah program yang menunjukkan kegiatan literasi bahasa berbasis kelas. Program literasi berbasis kelas dimaksud, yaitu (1) menciptakan ruangan kelas yang nyaman dan penuh dengan nuansa yang mendorong siswa untuk membaca dan menulis. Media belajar dan kata-kata inspirasi dan motivasi dipajang di dinding kelas; (2) mengembangkan budaya baca-tulis melalui pembiasaan siswa untuk membaca dan menulis secara kontinu (membaca buku sumber atau buku lainnya, lalu mengomentari dan atau merangkumnya sendiri). Hal ini sangat penting karena penggunaan buku cerita yang berhubungan dengan isi kurikulum dapat meningkatkan karakter siswa (kejujuran, kesabaran, dan kepatuhan untuk berdoa) bersamaan dengan kemampuan dalam mendengarkan dan membaca (Marhaeni, 2018:517). Lebih lanjut dijelaskan bahwa cerita dapat digunakan sebagai alat pendidikan karakter; (3) mendorong siswa untuk terus berkarya melalui membaca dan menulis, yakni dengan membuat buletin kelas atau majalah dinding (mading) kelas, yang dilanjutkan dengan mengadakan lomba mading antarkelas agar semakin menggairahkan setiap kelas dalam berkreasi melalui mading kelas; (4) mengembangkan perpustakaan, area baca-tulis, pustaka kelas atau pojok baca kelas (https://www.matrapendidikan. com/2018/12/penerapamprogram-literasi-berbasis-kelas.html).

Paparan di atas menunjukkan betapa pentingnya penataan kelas dan pelaksanaan program-program kelas yang akan menunjang terlaksananya literasi bahasa berbasis kelas. Melalui tulisan ini akan dipaparkan keterlaksanaan kegiatan literasi bahasa berbasis kelas pada sekolah dasar di Pulau Lombok dan alternatif solusi dalam mengoptimalkan pelaksanaan literasi bahasa berbasis kelas di sekolah dasar Pulau Lombok.

\section{Landasan Teori}

Peta jalan Gerakan Literasi Nasional Kemendikbud (2017) mendefinisikan literasi sebagai suatu rangkaian kecakapan membaca, menulis, dan berbicara, kecakapan berhitung, dan kecakapan dalam mengakses dan menggunakan informasi; (b) sebagai praktik sosial yang penerapannya dipengaruhi oleh konteks; (c) sebagai proses pembelajaran dengan kegiatan membaca dan menulis sebagai medium untuk merenungkan, menyelidik, menanyakan, 
dan mengkritisi ilmu dan gagasan yang dipelajari; dan (d) sebagai pemanfaatan teks yang bervariasi menurut subjek, genre,dan tingkat kompleksitas bahasa. Menurut Word Economic Forum (2016), peserta didik memerlukan 16 keterampilan agar mampu bertahan di abad XXI, yakni literasi dasar (bagaimana peserta didik menerapkan keterampilan berliterasi untuk kehidupan sehari-hari), kompetensi (bagaimana peserta didik menyikapi tantangan yang kompleks), dan karakter (bagaimana peserta didik menyikapi perubahan lingkungan mereka). Dalam lingkup karakter, Penguatan Pendidikan Karakter (PPK) di Indonesia mengacu pada lima nilai utama, yakni (1) religius, (2) nasionalis, (3) mandiri, (4) gotong royong, (5) integritas (Depdikbud, 2018).

Nilai karakter ini dapat terwujud melalui upaya untuk meningkatkan kecakapan multiliterasi peserta didik, dengan fokus pada literasi baca-tulis, literasi budaya dan kewargaan, literasi sains, literasi numerasi, literasi digital, dan literasi finansial. Adapun pembelajaran yang bersifat multiliterasi ini memadukan karakter dengan penekanan pada lima karakter PPK serta kompetensi abad ke-21, yakni kreativitas, kecakapan berpikir kritis, kemampuan komunikasi, serta kolaborasi. Dalam hal ini, diperlukan pengembangan budaya literasi yang berkesinambungan untuk menerjadikan literasi sebagai program yang akan menghasilkan generasi yang berkarakter. Menurut Beers dkk., 2009 (dalam Depdikbud, 2018), pembangunan budaya literasi di sekolah hendaknya berfokus pada tigal hal sebagai berikut. Pertama, mengondisikan lingkungan fisik yang kaya literasi. Kedua, mengupayakan lingkungan sosial dan afektif sebagai modal komunikasi dan interaksi yang literal. Ketiga, mengupayakan sekolah sebagai lingkungan akademik yang literal.

Terdapat sejulmah program yang dapat digunakan sebagai kegiatan untuk menterjadikan literasi bahasa berbasis kelas. Beberapa contoh program gerakan literasi bahasa berbasis kelas, antara lain (a) pemberdayaan mading setiap kelas, (b) membaca buku cerita sebelum proses belajar dimulai, (c) posterisasi kelas atau dinding motivasi kelas, (d) membuat pohon literasi atau papan karya di setiap kelas, dan (e) membuat sudut baca di setiap 
kelas(https://gurudigital.id/contohprogram-gerakan-literasi).

Dalam hal implementasi, diperlukan panduan dalam menerjadikan literasi di kelas, sekolah, maupun masyarakat. Menurut panduan literasi di $\mathrm{SD}$, peta konsep strategi literasi dalam pembelajaran (di kelas), terdiri atas serangkaian kegiatan untuk memahami teks, yaitu (a) menghubungkan teks dengan pengetahuan, pengalaman atau teks yang lain; (b) membuat inferensi atau prediksi tentang teks; (c) merumuskan pertanyaan; (d) memvisualisasikan pemahaman tentang teks; (e) mengidentifikasi ide penting/pokok dan pendukung; (f) mengomunikasikan pemahaman terhadap teks (Depdikbud, 2018). Lebih dari itu, semua kegiatan ini dilakukan sebelum, selama, dan sesudah membaca sebuah teks.

Pada dasarnya, Kurikulum 2013 telah menekankan implementasi strategi literasi untuk meningkatkan kecakapan berpikir tingkat tinggi peserta didik di SD. Terdapat sejumlah indikator yang menunjukkan kegiatan literasi telah terjadi dalam pembelajaran. Indikatorindikator dimaksud adalah sebagai berikut. a. Sebelum Pembelajaran: mengidentifikasi tujuan membaca/belajar; (b) membuat prediksi terhadap materi yang akan dipelajari, misalnya melalui fitur awal pada media pembelajaran (judul buku, judul film, dll.); (c) mendiskusikan materi yang akan dipelajari melalui media yang menyenangkan (buku pengayaan, dongeng, film pendek, dll.); dan (d) menghubungkan materi pembelajaran dengan pengalaman siswa/subtema pembelajaran sebelumnya.

b. Selama Pembelajaran: (1). Untuk SD Kelas Rendah: mengidentifikasi kosakata baru dan menebak maknanya melalui fitur teks (gambar atau konteks kalimat); (b) melafalkan kata-kata yang berulang dengan intonasi, pelafalan, dan irama yang benar; menggambar peta konsep sederhana; (d) bermain peran, menyanyi, atau menceritakan kembali untuk mengekspresikan pemahaman terhadap materi pembelajaran; dan (e) berdiskusi dengan teman dan bekerja dalam kelompok. (2) Untuk SD Kelas Tinggi: mengidentifikasi kosakata baru dan 
menebak maknanya melalui fitur teks (gambar atau konteks kalimat); (b) membuat peta konsep/graphic organizer untuk mengungkapkan pemahaman terhadap teks; (c) membuat catatan/ringkasan selama membaca; dan (d) Think aloud selama membaca dan mendiskusikan pemahamannya dengan guru/teman.

c. Setelah Pembelajaran: (a) mengambil kesimpulan tentang materi pembelajaran dan mengaitkannya dengan kehidupan sehari-hari; (b) melakukan refleksi terhadap proses pembelajaran; dan (c) melakukan konfirmasi terhadap prediksi/pertanyaan yang dibuat pada kegiatan pendahuluan.

\section{Metode Penelitian}

Secara metodologis, penelitian ini dilakukan melalui tiga tahapan, yaitu (1) tahap prapenelitian atau penyusunan proposal, penyusunan instrumen penelitian, dan penyiapan alat dan bahan penelitian; (2) tahap penelitian yang mencakup pengumpulan dan analisis data; dan (3) tahap pascapenelitian yang mencakup penyusunan laporan penelitian. Pengumpulan data melalui metode observasi dan FGD. Data terkait keterlaksanaan gerakan literasi bahasa berbasis kelas seperti jadwal pelaksanaan, program-program literasi, perangkat pembelajaran, dan sarana penunjang pelaksanaan literasi dikumpulkan melalui observasi. Sementara itu, data terkait penyebab dan alternatif solusi peningkatan gerakan literasi tersebut dikumpulkan melalui diskusi kelompok terpumpun (DKT). Analisis data dilakukan dengan mengikuti prinsip-prinsip dalam penelitian kualitatif, yaitu tahap reduksi data, penyajian atau organisasi data, dan verifikasi atau interpretasi data. Sementara itu, metode penyajian data dilakukan dengan metode formal dan nonformal (Mahsun, 2010).

\section{Pembahasan}

\subsection{Keterlaksanaan Literasi Bahasa} Berbasis Kelas di SD Pulau Lombok Belum Efektif

Penataan dan pengembangan program-program kelas untuk mendukung terlaksanaannya program literasi bahasa berbasis kelas tampaknya belum banyak dilakukan di sekolahsekolah.Hasil observasi di SDN 40 Cakranegara dan SDN 20 Mataram menunjukkan bahwa (a) penataan ruang kelas termasuk posisi meja belajar belum tertata baik; (b) kelas terlalu padat karena ukurannya kecil tetapi 
isinya banyak (sampai 42 orang); (c) ruangan kelas miskin dengan bahan cetak; dan (d) karya siswa tersimpan rapi dalam potofolio siswa di pojok/belakang kelas. Namun demikian, pada beberapa sekolah di kabupaten Lombok Barat, justru terjadi sebaliknya. Di SDN 1 Batu Kumbung, SDN 1 Batu Mekar, dan SDN 1 Lingsar penataan kelasnya sudah cukup mendukung untuk terlaksananya literasi kelas. Di tiga SD ini ditemukan (a) penataan ruang kelas yang nyaman, termasuk tata letak meja guru, meja siswa, dan fasilitas belajar lainnya; (b) terdapat pojok baca yang memiliki buku bacaan yang memadai (non pelajaran), termasuk buku pelajaran; (c) ruang kelas kaya dengan bahan cetak; (d) terdapat pohon pajanan atau papan pajanan untuk memamerkan hasil karya siswa; dan (e) setiap kelas memiliki mading.

GLS telah dilaksanakan sejak 2016, termasuk di Lompok. Pengamatan awal menunjukkan bahwa program literasi kelas belum berjalan secara efektif pada sekolah-sekolah di Kota Mataram dan Lombok Barat. Beberapa indikator yang menunjukkan masih belum efektifnya pelaksanaan literasi bahasa di Lombok adalah sebagai berikut.
Pertama, belum tersedia jadwal kegiatan atau program literasi kelas. Hampir semua sekolah tersebut, tidak bisa menunjukkan jadwal kegiatan atau program literasi kelas. Di setiap kelas juga tidak ditemukan, yang ada hanya jadwal literasi sekolah, yakni kegiatan rutun membaca bersama di lapangan atau aula sekolah. Semua wali kelas tidak dapat menunjukkan jadwal literasi di kelas (masing-masing kelas) dan hanya dapat menunjukkan jadwal literasi sekolah secara umum.

Kedua, kegiatan 15 menit membaca baru dilaksanakan secara bersama di halaman atau aula sekolah, yang di kelas masing-masing masih sangat jarang dilakukan (hanya dilakukan ketika materi pelajaran bahasa Indonesia). Namun demikian, semua wali kelas secara lisan menyatakan bahwa ada kegiatan 10 menit membaca di pojok baca kelas, terutama pada saat mata pelajaran/materi bahasa Indonesia. Hasil penelusuran terhadap siswa menunjukkan kegiatan tersebut tidak dilakukan setiap hari.

Ketiga, kegiatan literasi kelas belum tercermin pada perangkat pembelajaran yang dikembangkan guru. Pada semua perangkat pembelajaran 
(RPP) guru dari sekolah-sekolah yang dikunjungi belum ada satupun yang pada RPP-nya terdapat program literasi. RPP-nya masih sama dengan RPP pada umumnya.

Keempat, kegiatan litersi kelas belum tercermin pada kegiatan pembelajaran yang dilaksanakan guru. Pada semua tahapan pembelajaran yang dilaksanakan tidak ada yang mencerminkan kegiatan literasi. Hal ini karena memang dalam RPP guru juga tidak terdapat program literasi.

Kelima, hubungan sekolah dengan keluarga dan masyarakat belum terjalin dengan baik, termasuk dalam melaksanakan program literasi kelas. Hampir semua sekolah tersebut, belum melibatkan orang tua siswa (keluarga) dan masyarakat dalam melaksanakan kegiatan literasi kelas. Misalnya, sebagai model dalam pembelajaran/kegiatan literasi kelas. Menurut Elmacioğlu (2000), keberhasilan anak-anak di sekolah sangat terkait dengan lingkungan keluarga. Pollard dan Triggs (2000) juga menyatakan bahwa rumah, keturunan, evaluasi diri, dan usaha adalah di antara faktor-faktor yang mempengaruhi keberhasilan siswa (dalam Doğan dan Gönül Onur Sezer, 2010).
Berdasarkan uraian kondisi keterlaksanaan literasi bahasa di Lombok sebagaimana dipaparkan di atas, dapat disimpulkan bahwa program literasi bahasa berbasis kelas di Lombok belum berjalan secara efektif. Terdapat sejumlah penyebab kurang efektifnya program literasi bahasa berbasis kelas di Lombok. Penyebab-penyebab dimaksud tentu tidak akan lepas dari indikatorindikator kurang efektifnya program literasi bahasa berbasis kelas pada sekolah-sekolah yang juga telah dipaparkan di atas. Berikut dijabarkan beberapa penyebab kurang efektifnya program literasi bahasa berbasis kelas di Lombok.

1) Belum dilakukan penataan ruang kelas ke arah yang mendukung terselenggaranya kegiatan literasi bahasa di kelas. Pada sebagian besar kelas sekolah-sekolah tersebut, belum ada pojok baca kelas, belum ada papan/pohon pajanan untuk karya siswa, buku-buku pada pojok baca kelas belum memadai, kelas miskin dengan bahan cetakan.

2) Belum dilakukan perencanaan tau penyiapan program literasi bahasa berbasis kelas secara matang atau terkontrol. Sebagai buktinya, hampir pada semua sekolah tersebut belum 
tersedia jadwal kegiatan literasi kelas.

3) Belum diintegrasikan kegiatan literasi pada perangkat pembelajaran (RPP) yang dikembangkan guru. RPP yang dikembangkan belum satupun memuat kegiatan literasi.

4) Belum diintegrasikan kegiatan literasi pada kegiatan pembelajaran (pelaksanaan pembelajaran) yang dilaksanakan guru. Hal ini karena memang pada RPP juga belum dimasukkan kegiatan litersi.

5) Belum terjalin hubungan sekolah dengan keluarga dan masyarakat belum dengan baik. Termasuk dalam melaksanakan program literasi sekolah/kelas. Semua sekolah tersebut, belum melibatkan orang tua siswa (keluarga) dan masyarakat dalam melaksanakan kegiatan literasi, misalnya sebagai model.

\subsection{Sentuhan Teknologi Digital} sebagai Alternatif Optimalisasi Gerakan Literasi Bahasa Berbasis Kelas di Pulau Lombok

Pertanyaan yang harus dijawab berikutnya terkait belum efektifnya pelaksanaan kegiatan literasi bahasa berbasis kelas di SD Pulau Lombok adalah bagaimana mengoptimalkan kegiatan literasi tersebut agar menjadi efektif. Menurut hemat penulis dan berdasarkan hasil DKT dengan guruguru sekolah yang dikunjungi, beberapa hal yang harus dilakukan agar pelaksanaan kegiatan literasi bahasa berbasis kelas dapat berjalan dengan efektif adalah sebagai berikut. Uraian alternatif optimalisasi gerakan literasi dimaksud akan difokuskan dan dijabarkan berdasarkan berbagai penyebab kurang optimalnya pelaksanaan literasi sebagaimana telah dipaparkan di atas.

\section{1) Memberi Sentuhan Teknologi dalam Menata Struktur Kelas}

Menurut Beers, dkk. (2009), salah satu strategi untuk menciptakan budaya literasi yang positif di kelas adalah mengondisikan lingkungan fisik kelas menjadi ramah literasi. Dalam hal ini, lingkungan fisik kelas perlu terlihat ramah dan kondusif untuk pembelajaran. Kelas yang nyaman dan ramah untuk kegiatan literasi ditandai dengan penataan tertentu seperti: penataan pojok baca, pohon pajanan/papan pajanan, dinding motivasi, mading kelas. Hanover Research, juga menjelaskan bahwa desain sekolah untuk pendidikan abad 21 adalah menata ruang kelas dan 
lingkungan belajar lainnya dengan carayang memenuhi beragam kebutuhan belajar. (www.hanoverresearch.com). Kausar, dkk (2017) menemukan adanya pengaruh yang signifikan dari penataan ruang kelas terhadap prestasi akademik siswa. Penataan kelas yang efektif tidak hanya akan berdampak pada hasil belajar siswa, tetapi juga akan berakibat pada perubahan prilaku siswa. Menurut (Hannah, 2013), penataan kelas yang efektif dapat mengubah prilaku siswa.

Pada konteks ini, kelas untuk kegiatan literasi efektif di abad ini (termasuk di Lombok) hendaknya (1) ukurannya cukup luas sehingga memudahkan penataan dan penggantian posisi, (2) kelas kaya dengan bahan cetakan termasuk karya siswa, (3) kelas memiliki pojok baca yang dilengkapi buku yang memadai (tidak hanya buku pelajaran), (4) kelas memiliki papan, rak, atau pohon pajanan untuk karya siswa, (5) kelas memiliki majalah dinding, yang juga menampung karya siswa dan secara berkala diganti isinya, (6) kelas memiliki bank sumber belajar, ABP, dan sarana penunjang pembelajaran lainnya. Sangat ideal jika hal ini dapat dijelmakan dalam bentuk sumber digital.
Dengan perkembangan teknologi saat ini dan meningkatnya kebutuhan akan teknologi, akan sangat menunjang jika semua penataan kelas itu diberi sentuhan teknologi. Dalam hal ini, di kelas terdapat semacam laboraturium digital, yakni perangkat komputer yang dilengkapi berbagai data dan program untuk menunjang pelaksanaan pembelajaran dan literasi kelas. Dengan menggunakan perangkat komputer ini, siswa dapat membaca dan menulis berbagai bahan pustaka, siswa dapat mencari bahan pembelajaran, melakukan percobaan pembelajaran, mengikuti perlombaan, belajar mandiri, dan lain sebagainya secara daring (online).

Melalui pengembangan program pada lab digital ini, semua yang diperlukan akan muncul dalam satu kali sentuhan. Siswa akan melalukan apa saja kegiatan literasi atau pembelajaran, tinggal sentuh. Inilah yang penulis sebut sebagai sentuhan magis teknologi digital dalam penetaan ruang kelas literasi.

Boothe, Diane dan Linda Clark (2014) dalam tulisannya "The $21^{\text {st }}$ Century Classroom: Creating a Culture of Innovation in ICT" menyatakan bahwa para pimpinan sekolah dan pendidik mengakui bahwa kekuatan 
implementasi teknologi memiliki potensi untuk mengubah pendidikan. Ruang kelas di abad ke-21 mengalami transformasi yang cepat ke lingkungan belajar inovatif yang terhubung, fleksibel, dan kolaboratif karena adanya teknologi. Salah satu temuan Brown melalui penelitainnya yang berjudul Best Practices in $21^{\text {st }}$ Century Learning Environments: A Study of Two P21 Exemplar Schools tentang pembeda sekolah umum dengan sekolah teladan/model yang telah menerapkan program kemitraan untuk pendidikan abad 21 adalah pengalaman belajar sengaja diperluas (terhubung) ke dunia luar dengan memanfaatkan teknologi dan sumber daya yang ada. Dalam hal ini, sekolah-sekolah teladan tidak membatasi pengalaman belajar hanya di kelas. Sebaliknya, ada fokus yang di sengaja untuk memanfaatkan teknologi dan sumber daya yang tersedia untuk mengeksplorasi peluang belajar di luar gedung sekolah, baik secara fisik maupun virtual. Dalam hal ini, salah satu kerangka sekolah masa depan adalah guru dan siswa secara pribadi maupun berkelompok memanfaatkan teknologi dalam pembelajarannya di kelas (Brown, 2018:13).

\section{2) Mengembangkan Pemahaman} Komprehensif Pelaku Literasi Melalui Teknologi Digital

Guru, kepala sekolah, siswa, dan kompenen-komponen pendidikan seharusnya memahami secara mendalam kegiatan literasi kelas. Dengan pemahaman yang komprehensif, implementasi kegiatan literasi kelas akan terlaksana dengan baik. Guru akan dapat mennyusun, melaksanakan, dan mengevaluasi kegiatan literasi kelas dengan benar jika memiliki pemahanan tentang literasi kelas. Siswa akan dapat melaksanakan semua program literasi dengan baik dan penuh tanggung jawab jika memahami literasi secara mendalam. Kepala sekolah juga akan dapat memonitoring dan mendukung literasi kelas dengan benar jika memiliki pemahaman yang benar tentang literasi. Dalam konteks ini diperlukan berbagai pelatihan, pendampingan, dan bimbingan teknis terhadap pelaku literasi (terutama guru, kepala sekolah, siwa) secara kontinu dan berkesinambungan.

Dengan perkembangan teknologi seperti sekarang ini, pelatihan, pendampingan, dan bimbingan teknis terhadap pelaku literasi dapat dilakukan melalui sentuhan magis teknologi. Perlu 
dirancang program pelatihan, pendampingan, dan bimbingan teknis terhadap pelaku literasi berbasis teknologi digital agar dapat diakses setiap saat, di mana saja, kapan saja, dan oleh siapa saja.

3) Melatih Guru Merancang dan Melaksanakan Literasi dengan Memanfaatkan Teknologi Digital

Guru (utamanya guru kelas) harus dilatih dalam menyusun dan melaksanakan kegiatan literasi kelas. Guru kelas seharusnya terampil mengintegrasikan kegiatan literasi kelas pada RPP yang dikembangkan. Demikian pula, saat pembelajaran berlangsung, guru kelas selayaknya dapat mengembangkan kegiatan literasi yang terintegrasi dengan kegiatan pembelajarannya. Dengan kata lain, RPP yang dikembangkan semestinya menunjukkan RRP berbasis literasi dan pembelajaran yang dilaksanakan juga berbasis literasi.

Tentu akan semakin cepat dan mudah bila memanfaatkan teknologi digital. Pada konteks ini dirancang program pelatihan bagi guru dalam mengembangkan dan melaksanakan pembelajaran yang mendukung gerakan literasi berbasis kelas dengan memanfaatkan teknologi digital.
Berbagai jenis dan pilihan teknologi digital akan sangat membantu guru dalam meracang dan melaksanakan pembelajaran yang menarik dan menyenangan.

\section{4) Membangun Hubungan dengan} Keluarga dan Masyarakat dengan Memanfaatkan Teknologi Digital

Resep kedua yang ditawarkan Beers, dkk.(2009), sebagai strategi untuk menciptakan budaya literasi yang positif di sekolah adalah mengupayakan lingkungan sosial dan afektif sebagai model komunikasi dan interaksi yang literat. Lingkungan sosial dan afektif dibangun melalui model komunikasi dan interaksi pada seluruh komponen sekolah. Dalam hal ini, perlu dibangun hubungan yang harmonis dengan semua komponen pendidikan. Mabaso, 2017 melalui penelitiannya yang berjudul "Twenty-first century skills development in rural school learners" tentang bagaimana pengembangan keterampilan abad ke-21 pada pelajar sekolah pedesaan menunjukkan bahwa selain dengan penggunaan dan penguasaan teknologi, membangun hubungan dengan keluarga dan masyarakat akan sangat membatu dalam mengembangkan potensi siswa. Menurut Mabaso, hasil studi ini juga 
dapat dijadikan informasi/wawasan bagi organisasi atau praktisi yang ingin memperkenalkan lingkungan belajar mdern di sekolah-sekolah pedesaan.

Terkait dengan pelaksanaan literasi kelas, hubungan yang harmonis sekolah dengan semua komponen pendidikan tentu akan memudahkan pelaksanaan semua kegiatan literasi. Salah satu freamework pembaharuan atau pengembangan literasi yang dikemukakan International Literacy Association (2016), keluarga dan masyarakat. ILA menyakini bahwa keluarga dan masyarakat (terutama keluarga) merupakan kekuatan utama dalam pengembangan literasi.

Hasil observasi dan wawancara dengan beberapa sekolah swasta di Lombok (SDIT Anak Sholeh Mataram dan SD IT GMC Puyung) diketahui bahwa (1) hubungan sekolah dengan keluarga dan masyakarakat sangat baik. Dalam hal ini, banyak orang tua atau masyarakat yang ikut menjadi model pembelajaran di sekolah, kegiatan forum kelas berjalan setiap 3--4 minggu, ada kegiatan kunjungan ke rumah keluarga orang tua atau masyarakat sesuai tema pembelajaran bulan itu; (2) terdapat buku penghubung dan group sosial media antara wali kelas (pihak sekolah) dengan orang tua wali siswa; dan (3) terdapat "Program Anak MelaporkanOrang Tua Bercerita”. Dalam hal ini, pada setiap kegiatan outing class dan atau kunjungan lapangan, siswa akan melaporkan hasilnya kepada orang tuanya, lalu orang tua menceritakan kembali hasil laporan anaknya melalui tulisan untuk dikumpulkan kepada guru. Pada dua sekolah swasta tersebut, karakter siswa sangat kuat. Mulai kelas rendah (kelas 3), sebagian besar siswa pada sekolah tersebut: (a) telah terbisa membaca (bahkan keranjingan membaca), membaca telah menjadi kebutuhan anak; (b) terbiasa membuat laporan atas kegiatan yang dilakukan, membuat laporan pengamatan, laporan percobaan, dan review buku; (c) terbisa bekerjasama, berkomunikasi dengan semua elemen sekolah, dan menyampaikan pendapatnya dengan baik dan santun. Tentu hal ini, sangat sesuai dengan tuntuan nawacita literasi, yakni menumbuhkembangkan budi pekerti peserta didik melalui pembudayaan ekosistem sekolah yang diwujudkan dalam GLS agar mereka menjadi pembelajar sepandang hayat (Faizah, dkk., 2016). 
Akan menjadi lebih maksimal lagi, jika bangunan harmonis sekolah dengan semua elemen pendidikan tersebut ditopang oleh pemanfaatan teknologi digital dengan benar. Dalam hal ini, semua program literasi berbasis kelas sebagaimana telah dipaparkan pada bagian pengantar akan semakin cepat terlaksana dan dirasakan manfaatnya. Mengembangkan budaya baca-tulis melalui pembiasaan siswa untuk membaca dan menulis secara kontinyu (membaca buku sumber atau buku lainnya, lalu mengomentari dan atau merangkumnya sendiri) akan semakin efektif jika diberi sentuhan magis teknologi. Mendorong siswa untuk terus berkarya melalui membaca dan menulis, yakni dengan membuat buletin kelas atau majalah dinding (mading) kelas, yang dilanjutkan dengan mengadakan lomba-lomba juga akan semakin efektif melalui tambahan sentuhan magis teknologi.

\section{Penutup}

Pengembangan literasi termasuk literasi bahasa berbasis kelas tentu terus dilakukan. Termasuk dengan memanfaatkan teknologi. Salah satu teknologi pendidikan yang dapat digunakan, yaitu Augmented Reality
2D/3D ke dalam dunia nyata agar manusia dapat berinteraksi dengan komputer secara lebih alami. Augmented Reality (AR) adalah sebuah teknologi yang menggabungkan benda maya ke dalam sebuah lingkungan nyata. Teknologi ini menjadikan pembelajaran lebih menarik dan menyenangkan karena sesuai dengan kehidupan seharihari. Padmini dalam penelitiannya mengungkapkan bahwa teknologi pendidikan terbukti dapat digunakan untuk meningkatkan hasil prestasi peserta didik dan mutu pendidikan yang ada serta menciptakan proses belajar mengajar yang kreatif, inovatif, menarik dan menantang (dalam Rochmah dkk., 2018). Uji coba dan evaluasi terhadap semua program itu harus juga terus digalakkan.Termasuk pula diperlukan uji coba dan penelitian lebih lanjut tentang ide sentuhan magis teknologi ini dalam mengefektifkan pelaksanaan literasi bahasa berbasis kelas. Perlu dipetakan lebih detail kebutuhankebutuhan untuk pelaksanaan semua tahapan literasi bahasa berbasis kelas. Perlu dikembangkan idikator-indikator kegiatan literasi berbasis kelas pada semua tahapan literasi dimaksud, yakni pembiasaan, pengembangan, dan 
pembelajaran agar semakin mudah melakukan pemantauan dan evaluasi.

\section{Daftar Pustaka}

Beers, C. S., Beers, J. W., \& Smith, J. O. (2009). A principal's guide to literacy instruction.Guilford Press.

Boothe, D., \& Clark, L. (2014). The 21 st century classroom: Creating a culture of innovation in ICT. In Conference Proceedings.ICT for Language Learning.

Brown, Susan. (2018). Best Practices in $21^{\text {st }} \quad$ Century Learning Environments: A Study of Two P21 Exemplar Schools. Brandman University, Irvine, CaliforniaSchool of Education.https://digitalcommons. brandman.edu/cgi/viewcontent.cgi ?article $=1197 \&$ context $=$ edd_disse rtations, diakses 12 Oktoebr 2019

Depdikbud. (2018). Strategi Literasi dalam Pembelajaran di Sekolah Dasar (Modul Materi Penyegaran Instruktur Kurikulum 2013).Jakarta: Direktorat Pembinaan Sekolah Dasar, Dirjen Dikdasmen, Kementerian Pendidikan dan Kebudayaan

Doğan, Yadigar dan Gönül Onur Sezer. (2010). A Study on Learning Environments of Elementary School Students Taking Social Studies Course: Bursa Sample. "World Conference on Educational Sciences" (Istanbul, Turkey, February 4-8, 2010). coorganized by the Bahcesehir University. Turkey: Devid
Publishing, diakses 10 September 2019

Faizah, D.U., dkk. (2016). Panduan Gerakan Literasi Sekolah di Sekolah Dasar. Jakarta: Direktorat Pembinaan Sekolah Dasar, Dirjen Dikdasmen, Kemendikbud

Hanover Research, (2011) .School Structures that Support 21st Century Learning. 1101 Connecticut Ave. NW, Suite 300, Washington, DC $20036 \quad \mathrm{P}$ 202.756.2971 F 866.808.6585 www.hanoverresearch.com, diakses 20 September 2019

Hannah, R. (2013). The Effect of Classroom Environment on Student Learning. Western Michigan University ScholarWorks at WMU.https://scholarworks. wmich.edu/cgi/viewcontent.cgi?ar ticle $=3380 \&$ context $=$ honors these s, diakses 20 September $201 \overline{9}$

International Literacy Association. (2016). Frameworks for literacy education reform [White paper]. Newark, DE: Author.

Kausar, Ayesha at all. (2017). Effect of Classroom Environment on the Academic Achievement of Secondary School Students in the Subject of Pakistan Studies at Secondary Level in Rawalpindi District, Pakistan. Journal of Education and Practice ISSN 2222-1735 (Paper) ISSN 2222288X (Online) Vol.8, No.24, 2017 hal 56-63 www.iiste.org, diakses 10 November 2019

Mabaso, Bongani A. (2017). Twentyfirst century skills development in rural school learners. Published 
by the University of Cape Town (UCT) in termsof the nonexclusive license granted to UCT by the author.

Mahsun. (2010). Metode Penelitian Bahasa. Jakarta: Rajawali Press

Marhaeni, A.A.I.N., I Komang Wahyu Wiguna, I Made Gunamantha, and Nyoman Dantes. (2018) Content and Context: A Children's Book to SupportLearning in the 2013 Curriculum. Advances in Social Science, Education and Humanities Research, volume 178. 1st International Conference of Innovation in Education (ICoIE 2018)

Rochmah, Eliya, Erna Labudasari, dan Nurani Amalia. (2018). The Usefull of Augmented Reality Over the National Insight in Learning Era Disruption-Based. 1 st National Seminar on Elementary Education (SNPD 2018) SHEs: Conference Series 1 (1) (2018) 232-239 
